\title{
Effectiveness of Song, Drill and Game Strategy in Improving Mathematical Performance
}

\author{
Raymart O. Basco ${ }^{1}$ \\ ${ }^{1}$ College of Teacher Education- Laboratory School, Batangas State University ARASOF- Nasugbu, Philippines \\ Correspondence: Raymart O. Basco, Ph.D., College of Teacher Education- Laboratory School, Nasugbu 4231, \\ Philippines. E-mail:braymart83@gmail.com
}

Received: March 26, 2020; Accepted: April 13, 2020; Published: April 14, 2020

No special funding was given in conducting this study.

\begin{abstract}
This study examined the effectiveness of SoDriGa strategy in teaching mathematics among $4^{\text {th }}$-grade pupils of Batangas State University ARASOF- Nasugbu Laboratory School. The data from the results of TIMSS (2003) and PISA (2018) revealed that there were poor mathematical performances among Filipino learners. On the need to address this issue on enhancing mathematics instruction, it is imperative that relevant efforts to be conducted to improve performance among Filipino learners. The aforementioned innovation in teaching is consonant to the provisions of Section 10.2 paragraph (a), (d), and (k) of Republic Act 10533, Enhanced Basic Education Act of 2013, that the curriculum shall be learner- centered, contextualized, and flexible enough to enable and allow schools to localize and indigenize instructional materials. Using multiple pre- and post-tests design, the findings revealed that respondents consistently performed well in their post-test. The result suggested that SoDriGa was a helpful study tool as it increased cognitive gains, motivation and built positive attitude towards learning mathematics while pupils' mastery and retention of concepts being taught were improved. Thus, SoDriGa as an effective strategy may be adapted and implemented in schools to enhance mathematics' instruction and further improve pupils' performance.
\end{abstract}

Keywords: song, drill, games, sodriga strategy, mathematics teaching

\section{Introduction}

Mathematics can be considered as an instrument of knowledge, reasoning, and critical analysis of reality and the problems of the environment itself (Viladot, Casals, Hilton, \& Sanders, 2018). Accordingly, mathematical literacy for all learners is not the sole goal, but as well as the primordial purpose of mathematics taught all through basic education (UNESCO, 2012). However, as highlighted in the results of the assessment conducted by Programme for International Student Assessment (PISA, 2018), Filipino learners garnered an average of 353 points in mathematical literacy, which was considered inferior to the 489 points Organisation for Economic Co-operation and Development (OECD) average.

Additionally, out of 38 nations worldwide, who participated in the assessment in science and mathematics conducted by The Third International Mathematics and Science Study (TIMSS, 2003), Philippines ranked $36^{\text {th }}$ in mathematics. The figures are quite alarming, which imperatively suggest the poor mathematical performance of Filipino learners.

Report from the National Education Testing and Research Center (2012) reveals that the mean percentage scores for grade three, grade six, and high school students revealed to be $57.0 \%, 66.8 \%$, and $48.9 \%$, respectively which were quite far below from the set National Achievement Test (NAT) standard of the DepEd which was $75 \%$.

On the need to address this issue on enhancing mathematics instruction, it is imperative that relevant efforts be conducted to enhance mathematics instruction and effectively improve mathematical achievement among learners. SoDriGa strategy in this study is proposed by integrating song, drill, and game in teaching mathematical concepts among pupils. The aforementioned innovation in teaching is consonant to the provisions of Section 10.2 paragraph (a), (d), and (k) of Republic Act 10533, Enhanced Basic Education Act of 2013, that the curriculum shall be learner- centered, contextualized, and flexible which facilitate and consent schools to indigenize and localize their teaching resources. 
Perotta, et al. (2013) explained that game-based learning means the utilization of video games to reinforce the educative process. It encompasses technological expansions that intensify the lines between spaces, formats, practices and languages connected with video games that led to 'blended' experiences, which are not only limited to the video game alone (De Freitas \& Griffiths, 2008).

In using game-based learning, it is noteworthy to emphasize that it significantly improves cognitive achievement among learners versus traditional teaching methods (Vogel et al., 2006). Motivation can likewise be improved using e-games in teaching (Kebritchi et al., 2010). Ya-Ting (2012) suggests that by directly providing students with praise, encouragement, and reinforcement, gaming software helps students develop confidence and motivation to continue with the task. The author also perceived the game to have elicited learner curiosity.

In the study conducted by Papastergiou (2009), learners revealed that the game is more enjoyable and active. It never allows learners to get bored as compared to traditional teaching for the reason that they focus on an objective. This helps them to retain elements in their memory easily and understand concepts that are difficult in order to advance in the game. Fengfeng (2008 a and b) found that games encouraged a more optimistic mind-set to mathematics learning. Further, Fengfeng (2008b) also found that a cooperative structure (where learners worked together in the game space) was better than an individualistic or competitive structure at facilitating attitudes towards mathematics learning.

Governor (2011) explored teaching and learning science through songs, which is quite similar to the attempt of the present action research. Numerous researches found that songs positively impact on engaging learners, improving language, providing learners with different illustrations and explications of content assisting them to commit to memory science concepts, and facilitating a theoretical scaffold for building concepts.

Numerous studies have been conducted related to this research. For instance, Sagge and Bacio (2015) exclaimed that music was employed to improve learners' disposition, test anxiety, and habits of mind. From the study came the result that the pretest scores in habits of mind of the three groups were "not developed which were shifted to "strongly developed" for popular and alternative rock music group whereas urban music group was "satisfactorily developed" in the post test.

With the existing evidences, this research was conducted to examine the effectiveness of SoDriGa strategy in improving mathematical achievement among learners.

\subsection{The Use of Songs in Teaching}

As lifted from the Mathematics K-12 Curriculum (Revised 2016), mathematics is one subject that permeates existence at all periods and in several situations. Thus, its significance departs further than the classroom and the school. Mathematics as a subject in schools, consequently, has to be understood expansively and with enough profundity. The intertwined purposes of mathematics in the basic education levels, K-10, are critical thinking and problem-solving. Critical thinking, according to Scriven and Paul (1987) is the academically scientific practice of vigorous and proficient ability to conceptualize, apply, scrutinize, synthesize, and evaluate information collected from, or created by, examination, practice, manifestation, way of thinking, or communication, as a channel to principle and performance. On the other hand, according to Polya (1945 \& 1962), problem-solving in mathematical context is searching a means in the region of a complexity, around a difficulty, and uncovering an answer to a problem that is unidentified.

Yoho (2011) pointed out a general complaint amongst math teachers that learners do not recognize, recapture, or have adequate mastery of concept and content they have formerly been taught. Consequently, it becomes timeconsuming due to re-teaching or remedial teaching that needs to take place before the current curricular material can be taught to solve this problem is the lack of skill, knowledge, and retention among learners. Researches proves that traditional instructional methods of solving problems solely through paper and pencil and reading a textbook found to be inadequate for numerous learners to recognize and identify mathematical concepts.

Sangcap (2010) identified the positive and negative ideas of Filipino college students' $(n=336)$ about mathematics and mathematical problem. The study revealed the affirmative perceptions that Filipino students put premium importance on the endeavor in improving one's mathematical ability and identified mathematics as functional in their everyday lives. The findings were very significant since learners still viewed mathematics as useful in their daily lives; hence, value learning the subject.

According to Singer (2008), music increases the possibility learners had to understand; with music has been an approach to help in remembering information. 
The previous claim made by Singer (2008) was further supported by Pariakian and Lerner (2010) who observed that patterns might be accomplished with music. Learners construct stronger connections in life, increase retention of knowledge and their learning of numbers through recognition of pattern.

A related study was investigated by Sagge and Bacio (2015). They exclaimed that music was employed to improve learners' disposition, test anxiety, and habits of mind. From the study came the result that the pre-test scores in habits of mind of the three groups were "not developed which were shifted to "strongly developed" for popular and alternative rock music groups whereas the urban music group was "satisfactorily developed" in the post-test. The pre-test in disposition to the music of urban and alternative rock music group were both "partially liked," while popular music group was "liked". This shifted to "liked" in the post-test. The pre-test mean scores in test anxiety of the urban and popular music group were both "moderate" while the alternative rock music group was "high". On the one end, the post-test mean scores in test anxiety of the three groups improved to "moderate". As observed, all the background music utilized had an effect on the achievement of the students' scores in mathematics.

\subsection{The Use of Drills in Teaching}

Rathakrishnan, et.al. (2017) delved on the effectiveness of teaching and learning of the topic animals in science subject using the drilling and training method. The quasi-experimental research revealed that the results that drilling method in teaching the concept of animals is more effectual than the traditional method of learning. It was identified that the results of the post-test percentage is superior to pre-test. There was an affirmative response from learners during teaching and learning using the drilling method.

\subsection{The Use of Games in Teaching}

The teachers' use of games and innovative pedagogical applications might be helpful for enhancing students' attitudes towards mathematics (Afari, Aldridge, Fraser, \& Khine, 2013). Arthur, Badertscher, Goldenberg, Moeller, McLeod, Nikula, and Reed (2017) describe the characteristics of games. Accordingly, games can be utilized repeatedly several times, and their complexity can be diminished or intensified to maintain challenge as learners increase proficiency; they can involve learners in solving problems, discussing, and puzzling strategies as they play; they can comprehensively direct on learners to count, perform operations, geometry, and algebraic thinking, to identify some; and they develop learners to be persistent.

In addition to promoting persistence and problem-solving and fostering early math skills and knowledge, Arthur, Badertscher, Goldenberg, Moeller, McLeod, Nikula, \& Reed (2017) explain that games aid to increase learners' vocabulary and cultivate significant socio-emotional skills. Also, games help learners to understand the value of patience, taking turns, working well with others, and succeeding and struggling respectfully and graciously. All of these conduct of socializing with others are primordial not just in school or in math class, but in life in general.

Davies (1995) as cited by Gwongyosi (2018) identifies the advantages of using games in mathematics. It involves the following: meaningful situations- for the application of mathematical skills are created by games; motivationchildren freely choose to participate and enjoy playing; positive attitude - games provide opportunities for building self-concept and developing positive attitudes towards mathematics, through reducing the fear of failure and error; increased learning - in comparison to more formal activities, greater learning can occur through games due to the increased interaction between children, opportunities to test intuitive ideas and problem solving strategies.

Kagan and Lowenstein (2004) in Bose and Seetso (2016) propose that a combination of game-based learning and systematic instruction methods can improve the curriculum's effectiveness and relevance, as it is not solely an dynamic education method but also a supportive and community-based method, which refers to methods of education where learners work in teams to complete tasks inclusively and collectively towards academic objectives.

Games have significant position in learners' understanding of numbers and maintaining and initiating communications in mathematics (TrawickSmith, Swaminathan, \& Liu, 2016). Games increase verbal communication, creative and critical thinking skills, top-level social interaction skills, divergent and imaginary thinking skills and problem solving skills of learners (Wood \& Attfield, 2005).

Moreso, games can increase the effectiveness of the educative process by creating an environment where learners work together mutually and collaboratively and by providing discussion platforms (Turgut \& Temur, 2017).

\subsection{Objectives of the Study}

This study was conducted to examine the effectiveness of song, drill, and game (SoDriGa) strategy in teaching mathematics among $4^{\text {th }}$-grade pupils of Batangas State University ARASOF Nasugbu Laboratory School. In particular, this study focused on the performance of the respondents in the pre-test and post-test; the significant difference between the pre-test and post-test scores of the respondents; the effects SoDriGa strategy in improving 
mathematics performance as perceived by the pupils and teachers in terms of: cognitive gains, motivation, and Mathematics classes; and the action plan may be proposed to disseminate and utilize SoDriGa strategy results.

\subsection{Hypothesis}

There are no significant differences between the pre-test and post-test results of the respondents.

\section{Method}

\subsection{Research Design}

A quasi-experiment design with multiple pretest and posttest (Shadish, Cook, \& Campbell, 2002) based on one treatment group with four observations before and after the treatment was utilized in the current study for investigating the effects of SoDriGa strategy in teaching mathematics among $4^{\text {th }}$-grade pupils of Batangas State University ARASOF Nasugbu Laboratory School for SY 2019- 2020.

\subsection{Participants}

The participants of the study were $264^{\text {th }}$-grade pupils of Batangas State University ARASOF- Nasugbu Laboratory School for the school year 2019-2020. Total sampling was used to select the participants. The pupil-participants were taught using SoDriGa strategy.

\subsection{Data Gathering Procedure}

The researcher consulted the principal regarding the present action research. Upon the given approval from the principal, the pre-test was administered to the pupils. After every lesson, post-test was given to assess their mathematical performance. Likewise, a three- item open-ended questionnaire was prepared, validated, and given by the researcher to the participants to answer an open-ended questionnaire regarding the effects of the SoDriGA strategy in improving mathematics performance among grade 4 pupils.

\section{Results and Discussions}

\subsection{Performance of the Respondents in the Pre-Test and Post-Test}

The results of the pre-test and post-test of the respondents are revealed in Table 1.

Table 1. Respondents' Pre-test and Post-test Performance

\begin{tabular}{llll}
\hline & Mean & Standard Deviation & Mean Difference \\
\hline Post-Test 1 & 9.42 & 0.504 & 3.54 \\
Pre-Test 1 & 5.88 & 1.657 & \\
Post-Test 2 & 9.12 & 0.588 & 3.57 \\
Pre-Test 2 & 5.55 & 1.505 & \\
Post-Test 3 & 9.15 & 0.675 & 3.3 \\
Pre-Test 3 & 5.85 & 1.317 & \\
Post-Test 4 & 9.1 & 0.711 & 3.02 \\
Pre-Test 4 & 6.08 & 1.055 & \\
\hline
\end{tabular}

The results of the multiple pre-test and post-test results revealed in Table 1, shows that mean differences of 3.54, $3.57,3.30$, and 3.02 respectively proved the effectiveness of the SoDriGa strategy in teaching Mathematics among pupils. It further proves that through SoDriGa strategy increases the effectiveness of the educative process by creating an environment where learners work together mutually and collaboratively and by providing discussion platforms (Turgut \& Temur, 2017). Further it can be supported by the study of Afari, Aldridge, Fraser, and Khine (2013) that the use of SoDriGa strategy might be helpful for enhancing students' attitudes towards mathematics. It is significant since attitude in learning found to be a significant factor in effective instruction.

\subsection{Difference in the Respondents' Pre-Test and Post-Test Results}

Table 2 shows the difference in the pre-test and post-test of the respondents. 
Table 2. Difference in the Pre-Test and Post-Test Results of the Respondents

\begin{tabular}{llccc}
\hline & & t & df & Sig(2-tailed) \\
\hline Pair 1 & Post - Pre ... & 9.934 & 25 & .000 \\
Pair 2 & Post - Pre ... & 9.290 & 25 & .000 \\
Pair 3 & Post - Pre ... & 10.417 & 25 & .000 \\
Pair 4 & Post - Pre ... & 11.819 & 25 & .000 \\
\hline
\end{tabular}

From the pre-test and post-test results of the respondents, t-test revealed to have t-values of 9.934, 9.290, 10.417, and 11.819 which were all significant at 0.05 . It led to the rejection the null hypothesis; hence, there was a significant difference in the results of the pre-test and post-test of the respondents. Thus, it can be claimed that the utilization of SoDriGa strategy in teaching Mathematics can be an effective strategy to enhance pupils' performance in Mathematics. This positively affirmed the claim of Papastergiou (2009) and Kebritchi et al. (2010) that SoDriGa strategy increases enthusiasm and develops positive attitude towards learning thus, help pupils to retain concepts more easily. Further, this supported the argument of Ritzhaupt (2014) that the use of innovative educational games in a formal K-12 setting serves as a mediator for change in instructional delivery, teacher-tostudent relationships and student-to student, and as well as the abilities and characteristics of learners.

\subsection{Effects of SoDriGa Strategy}

There were several effects of SoDriga strategy in teaching Mathematics as perceived by the pupils. In terms of cognitive gains, a pupil respondent is quoted in saying, "through SoDriGa I can easily remember the concepts especially in examinations". It is further supported by teacher- respondents which reiterated that through the utilization of SoDriGa strategy, the development of skills would be easier because through the strategy concepts are practiced regularly. One teacher-respondent is quoted in saying, "through SoDriGa strategy pupils can easily memorize concepts being taught."

In viewing motivation, according to pupil respondents, they are more interested in learning mathematics concepts because of SoDriGa strategy. It is supported by one respondent saying, "it gives me energy all the time when we are singing, playing, and grouping". Further, the school head supported the result by saying, "SoDriGa strategy can arouse interest among pupils because of that it would be an enjoyable learning experience for them."

Generally, through the utilization of SoDriGa strategy in mathematics classes, positive attitude in learning mathematics was developed among learners. One teacher is quoted in saying, "SoDriGa strategy changed the way my pupils see mathematics". In order to validate this, one pupil-respondent is quoted in saying, "I am more excited to study mathematics because of the SoDriGa strategy."

\subsection{Action Plan}

Table 3 presents the action plan that can be proposed to disseminate and utilize the SoDriGa strategy to improve pupil's mathematical performance. The action plan was developed to share the results of the study among teachers. Further, this strategy may be adapted by teachers in their math classes so as to improve mathematical achievement among their learners.

Table 3. Action Plan

\begin{tabular}{lll}
\hline Areas of Concern & Information Dissemination & \\
\hline Objectives & $\begin{array}{l}\text { Disseminate the results of the study to improve } \\
\text { pupils' mathematical performance through the } \\
\text { application of the strategy. }\end{array}$ & $\begin{array}{l}\text { Create an online group for teachers } \\
\text { who are using SoDriGa strategy to } \\
\text { ask questions regarding the strategy. }\end{array}$ \\
\hline Ways and Means & $\begin{array}{l}\text { Conduct a research colloquium to be } \\
\text { participated by the educational leaders and } \\
\text { teachers }\end{array}$ & Create a group on Facebook. \\
\hline Persons Involved & $\begin{array}{l}\text { Educational leaders: division superintendent, district supervisor, school heads, } \\
\text { teachers, and researcher. }\end{array}$ & \\
\hline Time Frame & August - December 2020 & $\begin{array}{l}\text { An active Facebook group was made } \\
\text { were teachers freely exchange } \\
\text { information and experiences using } \\
\text { the strategy. }\end{array}$ \\
\hline Success Indicator & $\begin{array}{l}\text { Research colloquium was successfully } \\
\text { conducted were participants were well } \\
\text { acquainted of the SoDriGa strategy. Thus, } \\
\text { apply the strategy in their respective classes. }\end{array}$ & \\
\hline
\end{tabular}




\section{Conclusions and Recommendations}

The results of the study revealed that the post test results of the respondents improved statistically higher than their pre-test; SoDriGa strategy is effective in terms of improving mathematics instruction and mathematics performance of pupils; greater concept retention, increases pupils' motivation, and builds positive attitude towards learning mathematics were highly noted effects of SoDriGa strategy; and action plan is proposed to disseminate the results of the present study.

Based on the conclusions, the following recommendations were hereby advanced: SoDriGa strategy may be adapted by teachers in their math classes to improve mathematics instruction; SoDriGa strategy may be simplified in order for the pupils to self-operate the strategy; action plan may be adapted and implemented to disseminate and utilize the results of the study; and future researchers may explore utilizing SoDriGa strategy to different grade level and/or different subject area.

\section{Acknowledgments}

The author did not receive any funding in the conduct of the study. Also, sincerest gratitude is extended to the Mrs. Lorenjane E. Balan, Laboratory School Principal and Mrs. Lorna V. Dacillo, Elementary Coordinator for their limitless encouragement to conduct this quest for knowledge. Accordingly, the author wished to acknowledge Mrs. Alona M. Manalo for her valuable insights and constructive input in the preparation of the final manuscript.

\section{References}

Afari, E., Aldridge, J. M., Fraser, B. J., \& Khine, M. S. (2013). Students' perceptions of the learning environment and attitudes in game-based mathematics classrooms. Learning Environments Research, 16(1), 131-150. https://doi.org/10.1007/s10984-012-9122-6

Arthur, C., Badertscher, E., Goldenberg, P., Moeller, B., McLeod, M., Nikula, J., \& Reed, K. (2017). Strategies to improve all students' mathematics learning and achievement. Waltham, MA: EDC.Anderson, C. A., Gentile, D. A., \& Buckley, K. E. (2007). Violent video game effects on children and adolescents: Theory, research and public policy. https://doi.org/10.1093/acprof:oso/9780195309836.001.0001

Barker, C. (2008). Teacher, producer create CD for math success. New York Amsterdam News, 99(16), 32. Retrieved from Academic Search Premier database.

Beck, C. A. J., \& Sales, B. D. (2001). Family mediation: Facts, myths, and future prospects (pp. 100-102). Washington, DC: American Psychological Association. https://doi.org/10.1037/10401-000

Binkiewicz, D. (2006). Tunes of the times: historical songs as pedagogy for recent US history. History Teacher, 39(4), 515-520. Retrieved from Education Research Complete database. https://doi.org/10.2307/30037071

Bose, K., \& Seetso, G. (2016). Science and mathematics teaching through local games in preschools of Botswana. South African Journal of Childhood Education, 6(2), a453. https://doi. org/10.4102/sajce.v6i2.453

Crowther G. (2012). Using science songs to enhance learning: an interdisciplinary approach. CBE Life Sci. Educ., 11(1), 26-30. https://doi.org/10.1187/cbe.11-08-0068.

National Education Testing and Research Center. (2012). NAT overview and 2012 results.

De Freitas, S., \& Griffiths, M. (2008). The convergence of gaming practices with other media forms: what potential for learning? A review of the literature. Learning, Media and Technology, 33(1), 11-20. Department of Education. (2016). K to 12 science curriculum guide. https://doi.org/10.1080/17439880701868796

Department of Education. (2019). PISA 2018 national report of the Philippines. Department of Education Complex, Meralco Avenue, Pasig City, Philippines.

Fengfeng, K. (2008a). A case study of computer gaming for math: engaged learning from gameplay? Computers and Education, 51(4), 1609-1620. https://doi.org/10.1016/j.compedu.2008.03.003

Fengfeng, K. (2008b). Computer games application within alternative classroom goal structures: cognitive, metacognitive, and affective evaluation. Educational Technology Research and Development, 56(5-6), 539556. https://doi.org/10.1007/s11423-008-9086-5

Governor, D., Hall, J., \& Jackson, D. (2013). Teaching and Learning Science Through Song: Exploring the experiences of students and teachers. International Journal of Science Education, 35, 3117-3140. https://doi.org/10.1080/09500693.2012.690542

Kagan, S. L., \& Lowenstein, A. E. (2004). School readiness and children's play: Contemporary oxymoron or compatible option? In E.F. Zigler, D. G. Singer \& S. J. Bishop-Joseph (eds.), Children's play: The roots of 
reading, Zero to three Press, Washington, DC.

Kebritchi, M., Hirumi, A., \& Bai, H. (2010). The effects of modern mathematics computer games on mathematics achievement and class motivation. Computers and Education, 55(2), 427-443. https://doi.org/10.1016/j.compedu.2010.02.007

King, F. (2018). Music Activities Delivered by Primary School Generalist Teachers in Victoria: Informing Teaching Practice. Australian Journal of Teacher Education, 43(4). Retrieved from http://ro.ecu.edu.au/ajte/vol43/iss4/10

Lehtinen, E., Hannula-Sormunen, M., McMullen, J. \& Gruber, H. (In press). Cultivating mathematical skills: From drill-and-practice to deliberate practice. ZDM Mathematics Education.

Levine, L. J., \& Edelstein, R. S. (2009). Emotion and memory narrowing: a review and goal-relevance approach. Cognition Emotion, 23, 833-875. https://doi.org/10.1080/02699930902738863

National Education Testing and Research Center. (2012). NAT overview and 2012 results.

Papastergiou, M. (2009). Digital game-based Learning in high school Computer science education: impact on educational effectiveness and student motivation. Computers and Education, 52(1), 1-12. https://doi.org/10.1016/j.compedu.2008.06.004

Pariakian, R., \& Lerner, C. (2010). Beyond twinkle, twinkle: using music with infants and toddlers. YC: Young Children, 65(2), 14-19. Retrieved from Education Research Complete database.

Perrotta, C., Featherstone, G., Aston, H., \& Houghton, E. (2013). Game-based Learning: Latest Evidence and Future Directions (NFER Research Programme: Innovation in Education). Slough: NFER.

Polya, George. (1945 \& 1962). 4 Problem solving steps. Retrieved May 2015.

Rathakrishnan, M., Raman, A., \& Haniffa, M. (2017) . The effectiveness of drill and training methods in science subject among form one students.

Sagge, Roberto G., \& Bacio, Salvador P. (2015). Music: effects on students' habits of mind, disposition, and test anxiety as bases for the development of music enhanced mathematics program. Paper presented at the 3rd International Conference on education for Sustainable Development. Punta Villa Resort, Arevalo, Iloilo City, Philippines.

Scriven, M., \& Paul, R. (2015). Defining critical thinking, defining critical thinking.

Singer, M. (2008). Accessing the musical intelligence in early childhood education. Australian Journal of Early Childhood, 33(2), 49-56. Retrieved from Education Research Complete database. https://doi.org/10.1177/183693910803300208

Trawick-Smith, J., Swaminathan S., \& Liu, X. (2016) The relationship of teacher-child play interactions to mathematics learning in preschool. Early Child Development and Care , 186(5), 716-733. https://doi.org/10.1080/03004430.2015.1054818

Tsin, Y. P. (2015). Composing songs for teaching science to college students. Sunway College, Jalan University, Malaysia. Retrieved from http://www.hrpub.org

Turgut, S., \& Temur, O. (2017). The Effect of Game-Assisted Mathematics Education on Academic Achievement in Turkey: A Meta-Analysis Study. International Electronic Journal of Elementary Education, 10(2). https://doi.org/10.26822/iejee.2017236115

Viladot, L., Casals, A., Jilton, C., \& Saunders, J. (2018). The integration of music and mathematics education in Catalonia and England: Perspectives on theory and practice. https://doi.org/10.1080/14613808.2017.1290595

Vogel, J. J., Vogel, D. S., Cannon-Bowers, J., Bowers, C. A., Muse, K., \& Wright, M. (2006). 'Computer gaming and interactive simulations for learning: a meta-analysis. Journal of Educational Computing Research, 34(3), 229-243. https://doi.org/10.2190/FLHV-K4WA-WPVQ-H0YM

Wood, E., \& Attfield, J. (2005). Play, learning and the early childhood curriculum. London: Paul Chapman Publishing. https://doi.org/10.4135/9781446280393

Ya-Ting, C. Y. (2012). Building virtual cities, inspiring intelligent citizens: Digital games for developing students' problem solving and learning motivation. Computers and Education, 59(2), 365-377. https://doi.org/10.1016/j.compedu.2012.01.012 


\section{Copyrights}

Copyright for this article is retained by the author(s), with first publication rights granted to the journal.

This is an open-access article distributed under the terms and conditions of the Creative Commons Attribution license (http://creativecommons.org/licenses/by/4.0/). 